\title{
Research on the rule of law to reduce administrative cost of government
}

\author{
Yanfang Cui \\ Minjiang University, Law college, Fuzhou 350000, China
}

Keywords: Administrative costs of government; Current situation and problems; Deep reasons; the rule of law; Control measures

\begin{abstract}
Administrative law and economics combine to produce a whole new concept, administrative cost. Since the 1980s, the world's major countries have begun to focus on administrative costs. The main driving force of world administrative reform comes from the control and optimization of administrative costs. Our government is also facing the urgent problem of high administrative costs and so on. Analysis our country's government administrative cost and response the fourth plenary session of the party's 18 large and 18 "administration according to law, building the rule of law government, reduce administrative cost", research the cost control in the process of administrative legal system, for deepening the reform of the administrative management system, form a standardized behaviors, coordinated operation, fair and transparent, clean and efficient government is of great significance.
\end{abstract}

\section{Introduction}

Production data, labor, equipment and so on reflect the actual cost of production and operation process is "cost". In order to make the chaotic social order, blind in a planned way, the government needs to manage the different levels of the society as a whole, and to provide services, and this kind of cost management and service is needed to work. In other words, the government occupies a wide range of social resources and consumes the management and service process to provide various management and services for the society to function properly. Administrative cost is the cost of government in the management and service of social activities.

In our country, scholars have different definitions of the concept of "administrative cost". These different scholars have different opinions which influence the cognition of the concept. There are many professionals who emphasize that administrative costs are the expenses of people, wealth and things that the government undertakes when it is administratively in accordance with the law. Experts also pointed out that the government's most basic function is to "provide public services, social public responsibility", so administrative costs is that the government in the performance of the "public service" this function when the consumed cost; The third view is that administrative costs are expenses that should not be consumed by the government, such as the costs of improper conduct and work mistakes. Others reject the three points of view, pointing out that it refers to the sum of expenditures that the government spends on providing some useful services, which can be measured in terms of monetary value. These different views influence people's understanding of the concept of administrative cost and lead to people's cognition. In contrast, the author prefers a second view, which is the view that "the government assumes the social responsibility to fulfill the costs of public functions". Because in the second view is pointed out that the government's administrative costs at the same time, also has been clear about the society is the object of government services, at the same time also offered to provide public services is the main function of the government's.

With the rapid social progress, more and more people are paying attention to administrative costs, so the importance of administrative cost control is more prominent. Through the study of the basic theories of administrative costs, the author thinks that control administrative costs must be from the 
political, economic, legal, three aspects, and can effective control of the present condition of the high cost of government administration.

\section{Control the administrative cost method of government}

To carry out legal popularization and legal education work, and to enhance legal consciousness.. At present, the administrative system of our country is becoming more and more perfect, and the degree of legalization increases and the administrative personnel must abide by the higher rules and regulations of the law. Therefore, in order to adapt to the administrative system, the administrative personnel must have a good quality, sufficient knowledge of culture, more need to have a high legal cognition, and have excellent legal execution ability. However, the cognition of law is not arbitrary, but after a long training gradually formed, legal aspects to cultivate, to improve administrative cognitive ability of the law and enforce the law required level, etc. The cognitive ability and understanding of the law, and the degree of understanding, will have an indelible impact on the work of the administrative staff, and will guide them in the administration of the law. As long as the administrative person has the professional legal knowledge, the legal quality and the high degree of law grasp the ability, and then they have the power according to the law administrative, reasonable administration. So, for the cultivation of the administrative personnel work is particularly important and pays attention to grasp the way of training, to scientific and flexible, not dull, it is key link, and the combination of theory and practice in the study of law in the process of learning how to control desires in a cage.

In this way, can further carry out legal education work, for a long period of time for administrative personnel of legal knowledge and legal concepts of education, make them form a habit, when dealing with problems, the first thought is to solve in accordance with the law, will naturally administration according to law. In fact, the law consciousness of the form is very useful, it helps administrative personnel administration mode and method of curing formation, cultivate a batch of high quality, have the agile legal sense, a powerful legal consciousness of people is quite necessary. It is not enough to rely solely on legal consciousness, and a lot of work needs to be done. Second, the administrative personnel should be aware of the law consciously, and should be in awe of the law, obey, consciously carry out, impassable, and actively deal with it. Three, to have respect for the law consciousness, it is very necessary, the administrative personnel if awe, respect, from the bottom of the method as all the rules, administrative illegal phenomenon can be avoided, want to legal work, must want to have the fear of the legal point of view, otherwise, the law, is useless.

We will improve the legislative system and uphold the law to a high authority. At present, the government of our country has a lot of administrative and illegal behavior, which is related to the malpractice of relevant laws in China, because of the rule of law in China, the defect of law gives the administrative personnel a chance to take advantage of it. Therefore, our country must perfect and perfect the legal system, in the law to the administrative personnel's behavior standard, the scope of authority, the supervision system and so on detailed explanation. It must be clear and specific, and it is feasible to avoid some defects of real law, and it has a great hindrance to administrative illegal behavior. We should improve the legislative system and be able to avoid and manage administrative violations. Have appetites and desires for material, so there will be some official corruption phenomenon, trading power for money, they abuse their power to meet their own self-interest, the occurrence of these phenomena, also is the result of our country law loopholes, so it is necessary to reform the legal system of our country. So, there's an urgent need to be a law on punishing corrupt officials, such ability to control it, also has positive significance to the administrative, more need to get the law to establish scientific, rigorous, not for ideas, administrative person to claim. In addition to legislating to improve administrative levels, it is also important to maintain the supremacy of the law. Otherwise, the law did not have the authority and the rule of law in our country is a phantom, and socialist legal system countries also will not be able to continue to develop, high quality of law is not must exist, people will like, social unrest will continue. If have perfect legislation system, has a good legal talent, also introduced a very comprehensive and perfect laws and regulations, these alone will 
be able to manage and control of the government's administrative behavior, it is not possible. The supremacy of law cannot be underestimated. It is the premise of administration according to law. Otherwise, the law is as empty as a piece of paper. It has no effect. Also, the law is not to say that change can change, must be lasting effect, stable management, otherwise, people for their own self-interest, will own standards to judge whether the law applicable, it is not reasonable, law cannot as decoration, more should produce certain effect. That is to say, the law is at its highest level, and everyone must obey the law unconditionally, uphold the law, and net the law. The supreme expression is: the law can govern the country, above all, the government has its power to give, the government can only work according to law, violation of the law; In the rule of law, without any power beyond the law, political parties, governments and social organizations should work under the conditions of the law, and their policies and policies can't get rid of the law. From most people, then the leader's personal idea if contrary to the law, then take the law as heavy, people to obey the law, and must be unconditional, can appear the leader's behavior and thought of the law behavior, more can't according to the will of one person, to change the law, more can't exist any illegal restriction of government administrative events, otherwise will severely punish; As long as the violation of the law, the responsibility, regardless of status, wealth, gender and gender, all must be punished by the state.

Put supervision in an important position and improve supervision system. China's current state administrative system is not perfect, which has seriously affected the progress of socialist legal system construction in China, which has led to many illegal ACTS. Many system has a great influence on the our country government administration, and so, if you want to put an end to administrative illegal phenomenon in our country, should be timely to construct scientific and political system, the main should be administrative system, so our country's administrative system reform work cannot be lax. The need of perfecting the administrative system in our country, the system must be scientific and rational, efficient, low cost, administration according to law, that is to say, China should ensure the government's low cost, so for civil servants, must start from their own, temperance innocence, not corruption, not special, don't charge gray income, for the government, consider work consumed by human, financial and cost and energy cost. If a government as a whole is not clean, the administrative personnel corruption is not very difficult, because the reality of their grey income mostly in the form of group of collection, want them to ensure work efficiently and temperance, is difficult. Therefore, we should start from the whole to ensure that the whole government is clean and honest, which has positive significance to avoid the corruption and inefficiency of the administration. Therefore, the basic objective of our current administrative system is low government overall administrative cost and integrity. Moreover, while the administrative system is being carried out in China, the influence of supervision should not be underestimated; ensuring the integrity and science of the supervision system is the top priority. The current administrative system in China is flawed and lacks a complete supervision system, so it is difficult to avoid administrative violations. Our country must supervise the administration and intensify its efforts, because there are many practical problems, so that the supervision of the government must be carried out in the long run. The administrative supervision system includes the supervision of the administration by the state power, the supervision of social organizations, the supervision of democratic parties, and the supervision of citizens. The supervision of state power also includes the people's congress, the court, the procurator ate and the supervision of the government. The citizens' supervision includes the Suggestions of citizen criticism, the participation in the decision-making of the master and so on. Various forms of supervision, constitute a legal and scientific supervision system, the study of supervision main body, can be analyzed from various angles, can press the "power" "rights", "power" is the National People's Congress, the judicial organs to exercise the supervision of the organ of state power, "rights" is refers to in order to guarantee the exercise of the rights of citizens, supervise by citizens. Supervision content are many, all kinds of administrative behavior must be under the supervision of all aspects, never limits, both concrete and abstract administrative act, administrative behavior, whether internal or external so, all will be the supervision main body in accordance with law, regulation, such ability can avoid administrative illegal phenomenon. For the government reform, the main task is to improve the supervision system, 
safeguard the rights and interests of all kinds of supervision bodies, and use various channels to construct scientific supervision mechanism to avoid administrative violation.

\section{Efforts to tackle corruption need to be strengthened}

The government is the champion of the people's interests, and its metamorphism represents the loss of the interests of the people, so the anti-corruption work is particularly important, and it is also an effective measure to reduce administrative costs. Official corruption is a potential danger to the whole society, which is also a big reason to increase government costs. Because corruption has a close relationship with government expenditure and social resource consumption, it raises administrative costs. Therefore, the anti-corruption drive needs to be strengthened, and the root cause is to be solved. Therefore, it is necessary to strengthen the construction of clean government, reform government institutions, strengthen supervision, and at any time, education, and various factors combine to form a new type of anti-corruption system. The whole society should have a discipline of discipline and party to jointly lead and supervise the work expenditure ethos of government departments. Inner-party supervision mechanism and innovation, such as education, talk, ask, dispose steps is given priority to, must put the supervision of officials in important position, especially the leadership of the party, because they are core, the development of countries and parties is effective to promote the development of social strength, so not bad. It is important to put an end to the actions of joint and collective corruption. Once this happens, we will immediately investigate and intensify the investigation.

\section{Summary}

According to the above analysis, it can be seen that administrative violations are composed of many factors. So, want to big efforts to stop the behavior, guarantee the legal administration, several aspects that need to be considered, analyzing the specific issues and explore the corresponding measures to control the factors of the illegal behavior, form a complete, scientific, reasonable prevention mechanism of administrative law, to deal with the behavior at any time.

\section{References}

[1] WEN Xiao-ting, GONG Jiao-ying \& Liu Xiaoying. Benefit Analysis of E-government Construction, (Information Science, 2005), p.1470-1475.

[2] WANG Chang-sheng (ed.). 2007 Annual Blue Book of China's EGovernment, (Beijing: Social Sciences Academic Press, 2007), p.167. (In Chinese)

[3] HU Jin-tao. The Report to the 17th CPC National Congress, (Beijing, 2007), p. 15-16. (In Chinese)

[4] ZHOU Fa-qiang. The Problems and Develop Strategy of China Egovernment, (China Management Informationization, 2006), p. 89-90. (In Chinese)

[5] WANG Chang-sheng (ed.). 2008 Annual Blue Book of China's EGovernment, (Beijing: Social Sciences Academic Press, 2008), p. 67. (In Chinese) 